\title{
"Analisis Kajian Kelayakan Usaha Bum Des "Beriuk Berkarya" Desa Lando Unit Usaha Sistem Penyediaan Air Minum Desa Serta Perannya Dalam Peningkatan Pendapatan Asli Desa Tahun 2018/2019"
}

\author{
Qurratul Aini' ${ }^{1}$, Mawardi ${ }^{2}$ \\ ${ }^{1}$ Prodi pendidikan ekonomi, FISE Universitas Hamzanwadi \\ Email: qurratul77@gmail.com \\ ${ }^{2}$ Prodi pendidikan bahasa inggris, FKIP Universitas Gunung Rinjani \\ Email: amin.mawardi@yahoo.com
}

\begin{abstract}
The purpose of this study was to determine the feasibility of BUM Des "BERIUK BERKARYA" business of the stigma of the unit of the village Drinking Water Supply System both in term of Financial Aspects and Non-Financial Aspects as well as knowing how much the role in the Original Village Revenue was analyzed using Percentage Calculations. This research uses the feasibility study theory of BUM Deep business from Ibrahim in Hastowiyono and Suharyanto (2014). The method used is a qualitative method with a descriptive approach. Date collection techniques used are interviews, observation, documentation, and form. Date analysis used in this study is a non-financial feasibility analysis and a financial feasibility analysis that is measured from the investment assessment and percentage analysis. The results of the Non-Financial Feasibility analysis and feasibility of the Financial Aspect show that the village drinking water supply system business can be declared feasibility to run. While from the percentage analysis results, this business can play a role in increasing the original income of Lando village.
\end{abstract}

Keywords: Bussiness Feasibility Study, BUM Des, Drinking Water Supply System, Village Original Income.

\begin{abstract}
Abstrak
Tujuan penelitian ini adalah untuk mengetahui kelayakan usaha BUMDes "ARRAHMAN" Desa Lando Unit Sistem Penyediaan Air Minum Desa ini baik dari segi Aspek Finansial maupun Aspek Non Finansial serta mengetahui seberapa besar peranannya dalam Peningkatan Pendapatan Asli Desa yang dianalisis menggunakan Perhitungan Persentase. Penelitian ini menggunakan teori kajian kelayakan usaha BUMDes dari Ibrahim dalam Hastowiyono dan Suharyanto (2014). Metode yang digunakan adalah metode Kualitatif dengan Pendekatan Deskriptif. Tehnik pengumpulan data yang digunakan adalah wawancara, observasi, dokumentasi dan formulir. Analisis data yang digunakan dalam penelitian ini adalah analisis kelayakan non finansial dan analisis kelayakan finansial yang di ukur dari penilaian investasi serta analisis persentase .Hasil Analisis Kelayakan Non Finansial dan Kelayakan Aspek Finansial menujukkan bahwa usaha Sistem Penyediaan Air Minum Desa ini dapat dinyatakan layak untuk
\end{abstract}


dijalankan Sedangkan dari hasil Analisis Persentase bahwa usaha ini dapat berperan dalam peningkatan pendapatan asli desa Lando.

Kata Kunci : Kajian Kelayakan Usaha, BUM Des, Sistem Penyediaan Air Minum,Pendapatan Asli Desa.

\section{PENDAHULUAN}

Era otonomi telah banyak mendukung untuk lebih memperhatikan nilai-nilai yang berguna untuk mencapai kesejahteraan masyarakat serta menciptakan kemandirian daerah guna meningkatkan pendapatan asli desa dan peningkatan kehidupan yang lebih baik dalam bidang ekonomi, sosial dan politik. Dalam era otonomi juga perlu diberlakukan kebijakan yang memberikan akses dan memberikan kesempatan kepada desa untuk dapat menggali potensi, baik sumberdaya alam maupun sumberdaya manusia yang berada dalam wilayah desa tersebut, yang nantinya digunakan sebagai sumber pendapatan desa.

Undang-undang nomor 6 tahun 2014 tentang desa pada pasal 87 menyebutkan (Ayat 1) desa dapat mendirikan badan usaha milik desa yang disebut BUM Des, (Ayat 2) BUM Des dikelola dengan semangat kekeluargaan dan kegotongroyongan dan (Ayat 3) BUM Des dapat menjalankan usaha di bidang ekonomi dan/atau pelayanan umum sesuai dengan ketentuan peraturan perundang-undangan.

Badan Usaha Milik desa yang disingkat BUM Des adalah lembaga usaha desa yang dikelola oleh masyarakat dan pemerintah desa dalam upaya memperkuat perekonmian desa dan dibentuk berdasarkan kebutuhan masyarakat dan potensi desa. BUM Des merupakan bentuk kelembagaan desa yang memiliki kegiatan menjalankan usaha ekonomi atau bisnis untuk memperoleh manfaat yang berguna bagi kesejahteraaan masyarakat desa. Desa mendirikan BUM Des bukanlah semata-mata untuk mencari keuntungan ekonomi atau laba, akan tetapi meliputi pula manfaat sosial dan manfaat non ekonomi lainnya. Manfaat ekonomi yang ingin diperoleh dari usaha BUM Des adalah keuntungan atau laba secara finansial, PADes bertambah, terbukanya lapangan kerja baru bagi warga desa, dan kegiatan usaha ekonomi lain dari BUM desa. 
BUM Des sebagai lembaga desa yang menjalankan usaha ekonomi harus memperhatikan prinsip efesiensi dan efektifitas serta kehati-hatian dalam menjalankan usaha. Oleh karena itu, sebelum menjalankan suatu kegiatan usaha terlebih dahulu harus mempertimbangkan matang-matang kelayakan dari jenis usaha yang kan dijalankan itu. Keputusan untuk memilih jenis usaha menjadi bidang usaha BUM Des bukanlah persoalan yang mudah, bidang-bidang usaha yang direncanakan harus layak dijalankan. Cara yang lazim untuk menilai kelayakan usaha adalah dengan melakukan kajian kelayakan usaha. Karena dalam memulai suatu usaha tidak cukup hanya mengandalkan pengaman dan insting (naluri) saja.

Analisis kajian kelayakan usaha merupakan suatu kegiatan yang dilakukan secara mendalam untuk melihat sejauh mana manfaat yang dapat diproleh dari ide/gagasan bisnis, dengan cara menganalisis ide/gagasan bisnis tersebut apakah layak atau tidak untuk dilaksanakan. Pada dasarnya kajian kelayakan usaha dapat dilaksanakan untuk mendirikan usaha baru atau dapat pula dalam rangka pengembangan usaha yang sudah ada. Kajian kelayakan usaha tidak hanya diperlukan pada awal pendirian usaha saja, tetapi perlu juga dilakukan pada saat BUM Des hendak melakukan pengembangan usaha.

Tujuan dilakukannya kajian kelayakan usaha adalah untuk memperhitungkan keadaan internal dan eksternal desa sebagai acuan dalam perencanaan usaha ekonomi desa, memantapkan gagasan usaha ekonomi, merencanakan sumber daya manusia, memperhitungkan peluang dan resiko dan menentukan jenis usaha yang menguntungkan. Sedangkan aspek-aspek yang dikaji/dinilai dalam menentukan kelayakan usaha meliputi: aspek pasar dan pemasaran, aspek teknis dan teknologi, aspek manajemen dan SDM, aspek keuangan, aspek ekonomi, sosial budaya, politik dan lingkungan serta aspek hokum (yuridis).

Desa Lando merupakan salah satu desa dari 16 (enam belas) Desa yang ada di Kecamatan Terara. Saat ini Desa Lando telah membentuk Badan Usaha Milik Desa (BUM Des) yang dinamakan dengan BUM Des "BERIUK BERKARYA", 
yang di peroleh Melalui musyawarah yang dilaksanakan oleh pemerintah desa dengan masyarakat setempat yang ada di Desa Lando. Sedangkan unit usaha yang dimiliki atau dijalakan di desa Lando ini sudah lumayan beragam dan bervariatif, seperti yang dipaparkan pada tabel dibawah ini:

Tabel 1. Jenis/Unit Usaha BUM Des "BERIUK BERKARYA” Desa Lando

\begin{tabular}{llcc}
\hline \multirow{2}{*}{ No } & \multicolumn{3}{c}{ Jenis Usaha } \\
\cline { 2 - 4 } & \multicolumn{2}{c}{ Jasa } & Peternakan \\
\hline 1 & $\begin{array}{l}\text { Penyedian Air Minum Desa } \\
\text { (PAMDes) }\end{array}$ & Budidaya Ayam & Perdagangan Telur Ayam \\
\hline 2 & Agen LPG & - & - \\
\hline
\end{tabular}

Dari tabel di atas dapat dijelaskan bahwa dimana BUM Des "BERIUK BERKARYA" ini bergerak dalam (3) tiga jenis yaitu usaha jasa, peternakan dan perdagangan. Beberapa usaha ini di pilih, dengan tujuan untuk menambah ketersediaan barang-barang yang menjadi kebutuhan masyarakat, khususnya masyarakat yang berada di lingkup Lando. Dari jenis usaha jasa BUM Des "BERIUK BERKARYA" menyediakan antara lain jasa Penyediaan Air Minum Desa (PAMDes), dan Agen Elpiji (LPG). Sedangkan dari jenis usaha Peternakan yaitu Pembudidayaan Ayam Ternak serta dari jenis usaha Perdagangan yaitu Perdagangan Telur Ayam.

Dari hasil wawancara tentang usaha Desa Lando. Ketua pengelola BUM Des "BERIUK BERKARYA" mengaku bahwa, ada beberapa permasalahan yang terjadi terkait dalam menjalankan usaha BUM Des ini. Khususnya dari Sistem Penyedian Air Minum Desa (PAMDes), unit usaha ini berbeda dengan unit usaha yang lain. Karena usaha ini dijalankan sudah beberapa tahun yang lalu dan terhitung sudah 7 (tahun) berjalan. sehingga pemerataan dari unit usaha ini kepada masyarakat sudah dikatakan maksimal, karena dapat dilihat dari sebagian besar masyarakat desa Lando yang dapat menggunakan dan menikmati manfaat dari keberadaan unit usaha ini, dibandingkan dengan beberapa unit usaha yang lain yang masih tergolong baru. Yaitu baru dijalankan 1 (satu) tahun belakangan ini yang terhitung dari sejak pergantian Kepala Desa Lando pada tahun 2018. 
Sedangkan pada usaha BUM Des "BERIUK BERKARYA" Desa Lando terutama pada unit usaha Sistem Penyediaan Air Minum Desa ini belum sama sekali di dilakukan sebuah kajian kelayakan usaha dari dulu sampai sekarang. Pemerintah Desa juga tidak dapat mengetahui secara rinci unit usaha yang dijalankan oleh desa apakah berperan dalam meningkatan pendapatan asli Desa Lando atau tidak, mengingat sumbangan hasil usaha BUM Des "BERIUK BERKARYA” Desa Lando ini ditujukan paling banyak ialah untuk peningkatan pendapatan asli desanya. Berdasarkan pemaparan masalah di atas, maka peneliti tertarik untuk melakukan penelitian di Desa Lando Kecamatan Terara dengan judul “Analisis Kajian Kelayakan Usaha BUM Des “BERIUK BERKARYA” Desa Lando Unit Usaha Sistem Penyedian Air Minum Desa Serta Perannya Dalam Peningkatkan Pendapatan Asli Desa”.

\section{METODE PENELITIAN}

Metode dalam penelitian ini adalah termasuk ke dalam penelitian kualitatif dengan menggunakan pendekatan deskriptif. Tempat penelitian ini dilaksanakan di desa Lando, yaitu salah satu Desa di Kecamatan Terara Kabupaten Lombok Timur sedangkan waktu pelaksanaan penelitian di mulai pada bulan oktoberjanuari 2018/2019. Data dalam penelitian ini adalah data verbal yang berupa ucapan lisan yang merupakan jawaban terhadap kelayakan usaha BUM Des BERIUK BERKARYA Unit Usaha Sistem Penyediaan Air Minum Desa dan sumber data utama dalam penelitian ini adalah manusia yang disebut dengan informan penelitian, sedangkan jumlah informan dalam penelitian ini adalah 10 (sepuluh) orang informan.

Teknik pengambilan data yang digunakan dalam penpelitian ini adalah tehnik wawancara tidak terstruktur, observasi terstruktur, dokumentasi dan instrumen bantu yaitu formulir yang digunakan untuk menilai kelayakan usaha. Keabsahan data yang digunakan ada dua yaitu kredibilitas dan transferabilitas. Sedangkan tehnik analisis data yang digunakan yaitu menggunakan tehnik analisis kelayakan usaha yang dibagi menjadi dua tehnik analisis yaitu analisis kelayakan non finansial dan analisis kelayakan finansial serta tehnik analisis persentase. 


\section{HASIL PENELITIAN DAN PEMBAHASAN}

\section{a. Analisis Kelayakan Usaha}

1. Kajian kelayakan usaha BUM Des "BERIUK BERKARYA" Desa Lando Unit Usaha Sistem Penyediaan Air Minum Desa Dari Aspek Non Finansial.

Aspek-aspek yang di kaji dalam aspek non finansial adalah aspek pasar dan pemasaran, aspek tehnis dan teknologi, aspek manajemen dan sumberdaya manusia, aspek sosial budaya, ekonomi, politik, lingkungan hidup dan lingkungan usaha serta aspek yuridis.

a) Dari hasil analisis aspek pasar dan pemasaran menunjukkan bahwa unit usaha Sistem Penyediaan Air Minum Desa ini memang sangat diutuhkan oleh sebagian besar masyarakat desa Lando, Selain itu harga yang ditawarkan kepada masyarakat desa Lando sangat murah, yaitu $\mathrm{Rp} 300 / \mathrm{m}^{3}$. Sehingga setiap masyarakat memiliki daya/mampu untuk membeli ditambah uang infak sebesar Rp 2.000/bulan/pelanggan, selain itu dengan tidak adanya pesaing yang menjalankan usaha yang sama sehingga keadaan tersebut memperbesar peluang untuk memperoleh jumlah pelanggan atau konsumen yang semakin banyak mengingat jumlah konsumen baru mencapai setengah dari jumlah rumah tangga yang ada.

b) Dari hasil analisis aspek tehnis dan teknologi menunjukkan produk yang ditawarkan BUM Des "BERIUK BERKARYA" merupakan produk yang berkualitas, usaha ini juga didukung dari segi teknologi, teknologi yang digunakan cukup sederhana, yaitu dengan teknik pengaliran grafitasi bumi. Kegiatan usaha pengelolaan air minum sepenuhnya berada di dalam Desa Lando, hanya saja lokasi sumber air dari usaha ini berada di desa lain yaitu Desa Ceret Daya. Meskipun demikian masalah tersebut mudah diatasi dengan pemasangan perpipaan.

c) Dari hasil analisis aspek manajemen dan sumber daya manusia menunjukkan bahwa sebelum pengoperasian usaha ini terlebih dahulu 
pengurus BUM Des menyusun rencana kegiatan usaha. Penyusunan rencana pengelolaan air minum desa ini dilakukan secara partisipatif, Sedangkan pelaksanaan kegiatan usaha penyediaan air minum diyakini dapat berjalan lancar. Ini dikarenakan rencana kegiatan atau jenis pekerjaan telah dirumuskan dengan jelas, Pengendalian dapat dijalankan secara efektif, karena BUMDes "BERIUK BERKARYA" telah memiliki mekanisme laporan pertanggungjawaban atas pelaksanaan kegiatan usaha. Selain itu, tersedianya sumberdaya manusia yang terampil karena pengelola BUMDes "BERIUK BERKARYA" merupakan orang-orang yang memiliki kompetensi memadai dalam pengelolaan air.

d) Dari hasil analisis aspek sosial budaya, ekonomi, politik, lingkungan usaha dan lingkungan hidup menunjukkan bahwa dengan adanya usaha ini masyarakat merasa senang dan merasa sangat terbantu dan dapat merelai konflik antar warga dengan pengelola PAMDes, selain itu usaha ini juga telah dapat membuka kesempatan kerja baru bagi masyarakat Desa Lando. Usaha PAMDes ini sudah mendapat dukungan politik dari berbagai pihak yang terkait terutama dari pemerintah kabupaten,

e) Dari hasil diketahui bahwa unit usaha Sistem Penyediaan Air Minum Desa ini tidak memiliki badan hukum, hanya saja usaha ini telah diatur dalam perdes desa Lando lebih jelasnya di (peraturan desa Lando pasal: 06/BMDs TB/LB/KTB/V/2010 Tentang Pengelolaan Air. Sedangkan Lokasi atau tempat usaha PAMDes ini dijalankan memang sepenuhnya adalah tanah milik Desa Lando hanya saja lokasi sumber air yang dijadikan sebagai bahan baku usaha ini terdapat di desa lain atau diluar desa Lando yaitu di Desa Ceret Daya. Meskipun demikian usaha ini telah memilki izin dari masyarakat Desa Ceret Daya sehingga tempat/lokasi usaha PAMDes ini dijalankan bebas dari sengketa. 
2. Kajian kelayakan usaha BUM Des "BERIUK BERKARYA" Desa Lando Unit Usaha Sistem Penyediaan Air Minum Desa Dari Aspek Non Finansial.

a. Dana dan sumber dana

Tabel: 1

Dana investasi dan modal kerja unit usaha Sistem Penyediaaan Air Minum BUM Des "BERIUK BERKARYA" Desa Lando

\begin{tabular}{|c|c|c|c|c|}
\hline \multirow[t]{2}{*}{ No } & \multirow[t]{2}{*}{ Klasifikasi Modal } & \multicolumn{2}{|c|}{ Sumber dan Jumlah Dana } & \multirow[t]{2}{*}{ Jumlah } \\
\hline & & Pem. Desa & Pem. Kab & \\
\hline \multirow[t]{6}{*}{ A. } & Investasi & & & \\
\hline & Tanah dan bangunan & 3.500 .000 & & 3.500 .000 \\
\hline & Peralatan & & 252.474 .000 & 252.474 .000 \\
\hline & $\begin{array}{l}\text { Bahan, pemasnagan, } \\
\text { transfort }\end{array}$ & & 88.700 .000 & 88.700 .000 \\
\hline & Perlengkapan kantor & & 7.800 .000 & 7.800 .000 \\
\hline & Biaya lainnya & & 2.400 .000 & 2.400 .000 \\
\hline \multirow[t]{5}{*}{ B. } & Modal Kerja & & & \\
\hline & ATK & & 500.000 & 500.000 \\
\hline & Insentif pengelola & & 22.800 .000 & 22.800 .000 \\
\hline & Biaya reparasi & & 9.000 .000 & 9.000 .000 \\
\hline & \multicolumn{3}{|c|}{ Total Modal } & 387.174 .000 \\
\hline
\end{tabular}

Sumber : diolah oleh Peneliti, 2018

Lebih lanjut, hal yang perlu dilakukan adalah melakukan perhitungan biaya penyusutan terhadap investasi yang berbentuk harta tetap, misalnya gedung komputer, meja, kursi peralatan dan lain-lain. Perhitungan ini diperlukan untuk menghitungkan laba/rugi dari kegiatan usaha

Tabel: 2

Perhitumgan biaya penyusutan Investasi unit usaha Sistem Penyediaan Air Minum BUM Des "BERIUK BERKARYA" Desa Lando

\begin{tabular}{|c|c|c|c|c|c|}
\hline $\begin{array}{c}\mathrm{N} \\
\mathrm{o}\end{array}$ & $\begin{array}{l}\text { Janis } \\
\text { Harta }\end{array}$ & Harga Pokok & Nilai Residu & $\begin{array}{c}\text { Umur } \\
\text { Ekonomis }\end{array}$ & $\begin{array}{c}\text { Biaya } \\
\text { Depresiasi/ } \\
\text { Penyusutan }\end{array}$ \\
\hline 1 & $\begin{array}{l}\text { Meteran } \\
\text { air }\end{array}$ & 175.200 .000 & 157.680 .000 & 10 tahun & 17.520 .000 \\
\hline 2 & Pipa SNI & 7.200 .000 & 6.720 .000 & 15 tahun & 480.000 \\
\hline
\end{tabular}




\begin{tabular}{llcccr}
\hline 3 & $\begin{array}{l}\text { Sambun } \\
\text { gan L }\end{array}$ & 10.506 .000 & 9.805 .600 & 15 tahun & 700.400 \\
\hline 4 & $\begin{array}{l}\text { Double } \\
\text { Neppel }\end{array}$ & 7.008 .000 & 5.606 .400 & 5 tahun & 1.401 .600 \\
& & & & \\
\hline 5 & $\begin{array}{l}\text { Stop } \\
\text { kran }\end{array}$ & 52.000 .000 & 41.600 .000 & 5 tahun & 10.400 .000 \\
\hline 6 & $\begin{array}{l}\text { Kompute } \\
\text { r }\end{array}$ & 4.000 .000 & 3.200 .000 & 5 tahun & 800.000 \\
\hline 7 & Kursi & 500.000 & 450.000 & 10 tahun & 50.000 \\
\hline 8 & Meja & 1.800 .000 & 1.620 .000 & 10 tahun & 180.000 \\
\hline 9 & Almari & 1.500 .000 & 1.350 .000 & 10 tahun & 150.000 \\
& Arsip & & & & 31.681 .000 \\
\hline & Total & 259.714 .000 & & & \\
\hline
\end{tabular}

Sumber : diolah oleh Peneliti, 2018

b. Arus kas

Tabel: 3

Perkiraan arus kas unit usaha Sistem Penyediaan Air Minum BUM Des “BERIUK BERKARYA" Desa Lando

\begin{tabular}{|c|c|c|c|c|c|c|}
\hline $\mathrm{N}$ & \multirow[t]{2}{*}{ Uraian } & \multicolumn{5}{|c|}{ Tahun ke } \\
\hline $\mathrm{O}$ & & 1 & 2 & 3 & 4 & 5 \\
\hline 1 & $\begin{array}{ll}\text { Arus } & \text { Kas } \\
\text { Masuk (A) } & \end{array}$ & $\begin{array}{l}112.128 . \\
000\end{array}$ & $\begin{array}{l}114.528 . \\
000\end{array}$ & $\begin{array}{l}116.928 . \\
000\end{array}$ & $\begin{array}{l}119.328 . \\
000\end{array}$ & $\begin{array}{l}121.728 .00 \\
0\end{array}$ \\
\hline 2 & $\begin{array}{ll}\text { Arus } & \text { Kas } \\
\text { Keluar (B) } & \end{array}$ & $\begin{array}{l}32.300 .0 \\
00\end{array}$ & $\begin{array}{l}32.300 .0 \\
00\end{array}$ & $\begin{array}{l}32.300 .0 \\
00\end{array}$ & $\begin{array}{l}32.300 .0 \\
00\end{array}$ & 32.300 .000 \\
\hline 3 & $\begin{array}{l}\text { Arus Kas Bersih } \\
\text { (A-B) }\end{array}$ & $\begin{array}{l}79.828 .0 \\
00\end{array}$ & $\begin{array}{l}82.228 .0 \\
00\end{array}$ & $\begin{array}{l}84.628 .0 \\
00\end{array}$ & $\begin{array}{l}87.028 .0 \\
00\end{array}$ & 89.428 .000 \\
\hline
\end{tabular}

Sumber : diolah oleh Peneliti, 2018

c. Laba rugi

Tabel: 4

Proyeksi Laba Rugi Unit Usaha Sistem Penyediaan Air Minum BUM Des "BERIUK BERKARYA” Desa Lando

\begin{tabular}{|c|c|c|c|c|c|c|}
\hline $\mathrm{N}$ & \multirow[t]{2}{*}{ Uraian } & \multicolumn{5}{|c|}{ Tahun ke } \\
\hline $\mathrm{o}$ & & 1 & 2 & 3 & 4 & 5 \\
\hline A & Penjualan & $\begin{array}{l}112.128 . \\
000\end{array}$ & $\begin{array}{l}114.528 \\
.000\end{array}$ & $\begin{array}{l}116.928 . \\
000\end{array}$ & $\begin{array}{l}119.328 . \\
000\end{array}$ & $\begin{array}{l}121.728 . \\
000\end{array}$ \\
\hline B & $\begin{array}{l}\text { Biaya } \\
\text { produksi }\end{array}$ & - & - & - & - & - \\
\hline $\mathrm{C}$ & Laba kotor $(\mathrm{A}-\mathrm{B})$ & $\begin{array}{l}112.128 . \\
000\end{array}$ & $\begin{array}{l}114.528 \\
.000\end{array}$ & $\begin{array}{l}116.928 . \\
000\end{array}$ & $\begin{array}{l}119.328 . \\
000\end{array}$ & $\begin{array}{l}121.728 . \\
000\end{array}$ \\
\hline $\mathrm{D}$ & biaya usaha & $\begin{array}{l}63.981 .0 \\
00\end{array}$ & $\begin{array}{l}63.981 . \\
000\end{array}$ & $\begin{array}{l}63.981 .0 \\
00\end{array}$ & $\begin{array}{l}63.981 .0 \\
00\end{array}$ & $\begin{array}{l}63.981 .0 \\
00\end{array}$ \\
\hline$E$ & Laba usaha (C-D) & 48.147 .0 & 50.547. & 52.947 .0 & 55.347 .0 & 57.747 .0 \\
\hline
\end{tabular}




\begin{tabular}{llccccc}
\hline & & 00 & 000 & 00 & 00 & 00 \\
\hline F & Bunga & - & - & - & - & - \\
\hline G & Laba sebelum pajak & 48.147 .0 & 50.547. & 52.947 .0 & 55.347 .0 & 57.747 .0 \\
& (E-F) & 00 & 000 & 00 & 00 & 00 \\
\hline H & Pajak & - & - & - & - & - \\
\hline I & Laba bersih $(\mathrm{G}-\mathrm{H})$ & 48.147 .0 & 50.547. & 52.947 .0 & 55.347 .0 & 57.747 .0 \\
& & 00 & 000 & 00 & 00 & 00 \\
\hline
\end{tabular}

Sumber : diolah oleh Peneliti, 2018

d. Penilaian Investasi Rencana Usaha.

1) Metode Pay Back Period.

Pay Back Period yaitu suatu periode yang diperlukan untuk menutup kembali pengeluaran investasi dengan menggunakan aliran kas. Usulan investasi dapat diterima jika Pay Back Period lebih pendek waktunya dari maksimum pay back yang diterima.

$$
\begin{aligned}
\text { Pay Back Period }= & \mathrm{n}+(\mathrm{a}-\mathrm{b}) /(\mathrm{c}-\mathrm{d}) \times 1 \text { tahun. } \\
= & 4+(\mathrm{Rp} 351.374 .000-\mathrm{Rp} \\
& 333.712 .000) /(\mathrm{Rp} 423.140 .000-\mathrm{Rp} \\
& 333.712 .000) \times 1 \text { tahun. } \\
= & 4+(17.635 .000) /(89.428 .000) \times 1 \text { tahun. } \\
= & 4,20 \text { tahun atau } 4 \text { tahun } 2 \text { bulan. }
\end{aligned}
$$

2) Metode Net Present Value.

Metode Net Present Value digunakan untuk melihat nilai sekarang dengan menghitung selisih antara biaya investasi dengan penerimaan-penerimaan kas bersih. Sedangkan untuk menghitung nilai sekarang perlu ditentukan tingkat suku bunga yang berlaku. Suku bunga bank 5,25\% per tahun (SBI Tahun 2018). Berdasarkan data tersebut, maka dapat diperhitungkan Net Present Value sebagai berikut:

Tabel: 5

Perhitungan Net Present Value Arus Kas Bersih Unit Usaha Sistem Penyediaan Air Minum BUM Des "BERIUK BERKARYA" Desa Lando

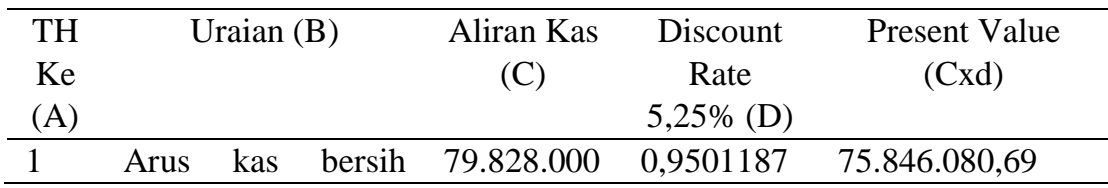




\begin{tabular}{|c|c|c|c|c|}
\hline & tahun ke-1 & & 64 & \\
\hline 2 & $\begin{array}{l}\text { Arus kas bersih } \\
\text { tahun ke-2 }\end{array}$ & 82.228 .000 & $\begin{array}{l}0,9027256 \\
67\end{array}$ & $74.229 .326,15$ \\
\hline 3 & $\begin{array}{l}\text { Arus kas bersih } \\
\text { tahun ke-3 }\end{array}$ & 84.628 .000 & $\begin{array}{l}0,8576965 \\
96\end{array}$ & $72.242 .068,89$ \\
\hline 4 & $\begin{array}{l}\text { Arus kas bersih } \\
\text { tahun ke-4 }\end{array}$ & 87.028 .000 & $\begin{array}{l}0,8149136 \\
3\end{array}$ & $70.920 .303,39$ \\
\hline 5 & $\begin{array}{l}\text { Arus kas bersih } \\
\text { tahun ke-5 }\end{array}$ & 89.428 .000 & $\begin{array}{l}0,7742647 \\
31\end{array}$ & $69.240 .946,36$ \\
\hline \multicolumn{4}{|c|}{ Total Nilai Sekarang (1) } & $362.478 .725,5$ \\
\hline \multicolumn{4}{|c|}{ Investasi Awal (2) } & 351.374 .000 \\
\hline \multicolumn{4}{|c|}{ Nilai Sekarang Bersih (1-2) } & $11.104 .725,5$ \\
\hline
\end{tabular}

Berdasarkan perhitungan Net Present Value di atas, maka dapat disimpulkan bahwa rencana kegiatan usaha Sistem Penyediaan Air Minum BUM Des "BERIUK BERKARYA" Desa Lando layak untuk dijalankan, karena Net Present Value sama dengan Rp 11.104.725,5. Berarti Net Present Value > 0 (bernilai positif).

3) Metode Profitability Index.

Metode ini digunakan untuk mengetahui unit usaha yang dijalankan apakah mendapatakan untung atau tidak. kriteria penilaian PI yaitu, jika PI > 1 maka usulan rencana usaha menguntung sedangkan jika PI $<1$ maka usulan rencana usaha tidak menguntungkan.

$$
\begin{aligned}
\mathrm{PI} & =\mathrm{PV} \text { kas masuk : PV kas keluar } \\
& =\mathrm{Rp} 423.140 .000: \operatorname{Rp} 351.374 .000 \\
& =1,20 .
\end{aligned}
$$

4) Break Event Point.

Unit usaha akan dapat dikatakan berada pada titik impas jika keadaan menunjukkan total pendapatan sama dengan total biaya.

BEP = biaya tetap : (harga jual per unit - biaya variabel rata-rata)

$$
\begin{aligned}
& =2,305:(300-0) \\
& =7,7
\end{aligned}
$$


Tabel: 6

Perhitumgan titik impas volume air unit usaha sistem penyediaan air minum BUM Des "BERIUK BERKARYA" Desa Lando

\begin{tabular}{cccccc}
\hline $\begin{array}{c}\text { Th } \\
\text { Ke }\end{array}$ & $\begin{array}{c}\text { Jumlah Pelanggan } \\
(\mathrm{RT})\end{array}$ & $\begin{array}{c}\text { Biaya } \\
\text { Tetap }\end{array}$ & $\begin{array}{c}\text { Harga } \\
\text { Jual }\end{array}$ & $\begin{array}{c}\text { Biaya } \\
\text { Variabel }\end{array}$ & $\begin{array}{c}\text { Volume Titik } \\
\text { Impas (M3) }\end{array}$ \\
\hline 1 & 1.168 & 2.305 & 300 & 0 & 7,68 \\
\hline 2 & 1.193 & 2.256 & 300 & 0 & 7,52 \\
\hline 3 & 1.218 & 2.209 & 300 & 0 & 7,36 \\
\hline 4 & 1.243 & 2.165 & 300 & 0 & 7,22 \\
\hline 5 & 1.268 & 2.123 & 300 & 0 & 7,077 \\
\hline
\end{tabular}

Sumber : diolah oleh Peneliti, 2018

3. Analisis Persentase Kenaikan Pendapatan

Tabel: 7

Rincian Bagi Hasil Usaha Sistem Penyediaan Air Minum BUM Des "BERIUK BERKARYA" Desa Lando

\begin{tabular}{|c|c|c|c|c|c|c|c|c|}
\hline \multirow[b]{2}{*}{$\begin{array}{l}\mathrm{TH} \\
\mathrm{Ke}\end{array}$} & \multirow[b]{2}{*}{$\begin{array}{l}\text { Laba } \\
\text { Usaha }\end{array}$} & \multicolumn{7}{|c|}{ Rincian Bagi Hasil Usaha } \\
\hline & & $\begin{array}{l}\text { Penambahan } \\
\text { Modal } \\
(22 \%)\end{array}$ & $\begin{array}{l}\text { Pendapatan } \\
\text { Asli Desa } \\
(40 \%)\end{array}$ & $\begin{array}{l}\text { Penasehat } \\
(4 \%)\end{array}$ & $\begin{array}{l}\text { Badan } \\
\text { Pengawas } \\
(4 \%)\end{array}$ & $\begin{array}{l}\text { Pelaksana } \\
\text { Operasional } \\
(15 \%)\end{array}$ & $\begin{array}{l}\text { Pendidikan } \\
\text { dan Sosial } \\
(10 \%)\end{array}$ & $\begin{array}{l}\text { Cadangan } \\
(5 \%)\end{array}$ \\
\hline 1 & 48.147 .000 & 10.592 .340 & 19.258 .800 & 1.925 .880 & 1.925 .880 & 7.222 .050 & 4.814 .700 & 2.407 .350 \\
\hline 2 & 50.547 .000 & 11.120 .340 & 20.218 .800 & 2.021 .880 & 2.021 .880 & 7.582 .050 & 5.054 .700 & 2.527 .350 \\
\hline 3 & 52.947 .000 & 11.648 .340 & 21.178 .800 & 2.117 .880 & 2.117 .880 & 7.942 .050 & 5.294 .700 & 2.647 .350 \\
\hline 4 & 55.347 .000 & 12.176 .340 & 22.138 .800 & 2.213 .880 & 2.213 .880 & 8.302 .050 & 5.534 .700 & 2.767 .350 \\
\hline
\end{tabular}

Dari kegiatan unit usaha Sistem Penyediaan Air Minum BUM Des "BERIUK BERKARYA" Desa Lando diketahui bahwa pendapatan asli desa yang diterima dalam kegiatan unit usaha ini adalah sebesar Rp.20.218.800 (tahun ke-2) - Rp.19.258.800 (tahun ke1) = Rp.960.000 kenaikan laba dalam satu tahun (tahun 1 ke 2). Setelah di ketahui besaran kenaikan pendapatan, maka selanjutnya dapat dihitung dengan rumus persentase untuk mengetahui berapa persen kenaikan pendapatan dalam satu tahunnya.

Persentase Kenaikan Pendapatan = Jumlah Kenaikan Pendapatan :

$$
\begin{aligned}
& \text { Jumlah Awal Pendapatan x 100\% } \\
= & \text { Rp.960.000: } 19.258 .800 \times 100 \% \\
= & 4,985 \% \text {-. }
\end{aligned}
$$

Karena peningkatan jumlah pelanggan air minum BUM Des "BERIUK BERKARYA” Desa Lando ini diasumsikan tetap yaitu 25 rumah tangga 
per tahun. Sehingga berdasarkan perhitungan persentase di atas maka dapat disimpulkan bahwa unit usaha ini dapat berkontribusi/berperan dalam peningkatan pendapatan asli desa yaitu sebesar $4,985 \%$ setiap tahunnya.

\section{KESIMPULAN}

Dilihat dari analisis kajian kelayakan usaha yang dilakukan baik dari analisis non finansial dapat disimpulkan layak untuk dijalankan karena setiap aspek yang terkait seperti dari aspek pasar dan pemasaran, aspek tehnis dan teknologi, aspek manajemen dan sumber daya manusia, aspek sosial budaya, ekonomi, politik, lingkungan usaha dan lingkungan hidup serta dari aspek yuridis menunjukkan bahwa semua unsur di setiap aspek tersebut sudah memenuhi syarat layak usaha. Sedangkan hasil analisis finansial kelayakan usaha, unit usaha Sistem Penyediaan Air Minum BUM Des "BERIUK BERKARYA" Desa Lando juga dapat disimpulkan layak untuk dijalankan yang dapat dilihat dari penilaian investasi seperti dengan metode pay back period yang di peroleh nilai 4,20 tahun atau 4 tahun 3 bulan, lebih cepat dari waktu maksimum yang dapat diterima yaitu 5 tahun. Selanjutnya dengan metode net present value diperoleh nilai NPV sebesar Rp 11.104.725,5 yang berarti NPV > 0 (bernilai positif), selain itu dengan menngunakan metode profitability index diperoleh nilai PI sebesar 1,20 yang berarti PI > 1. Sedangkan dengan menggunakan metode break event point diperoleh nilai kurang lebih $7 \mathrm{~m}^{3} /$ pelanggan/bulan. sedangkan volume rata-rata pemakaian setiap pelanggan pada kenyataannya adalah $15 \mathrm{~m} 3 /$ pelanggan/bulan.

Dari hasil analisis persentase menunjukkan bahwa unit usaha Sistem Penyediaan Air Minum Desa ini berperan dalam Peningkatan Pendapatan Asli Desa, dibuktikan dengan jumlah laba yang diterima yaitu sebesar 4,985\% setiap tahunnya

\section{DAFTAR RUJUKAN}

Ade Eka Kurniawan. (2015). Peranan Badan Usaha Milik Desa (Bumdes) dalam Peningkatan Pendapatan Asli Desa (Desa Lanjut Kecamatan Singkep Pesisir Kabupaten Lingga Tahun 2015).Public Administration Journal. Volume 3, Nomor 1, Hal 1-33. 
Anastasia Susty Ambarriani. (2014). Analisis Kelayakan Bisnis Es Bang Joe diPurwokerto. Volume 03, Nomor 01, Hal 1-9.

Egy, R. (2009). Standar Minimal Penyediaan Air Bersih Sanitasi di Daerah Bencana. Diunduh di http://elearning gunadarma.ac.id/docmodul/rekayasalingkungan/bab2 sistem penyediaan air bersih tanggal 12 April 2018.

Hastowiyono \& Suharyanto (2014).Penyususnan Kelayakan Usaha \&Pengembangan Usaha BUM Desa. Yogyakarta: Forum Pengembangan Pembaharuan Desa.

Hermanto Rohman, Joko Mulyono. (2016). Studi Kelayakan Pemberdayaan Usaha Ekonomi Pedesaan Bagi Terwujudnya Desa Mandiri di Kabupaten Banyuwangi. Volume 28 (2) 155.167, Hal 1-14.

Undang-Undang Nomor 6 Tahun 2014 tentang desa dan Peraturan Dalam Negeri Nomor 113 Tahun 2014

Permendagri Nomor 39 Tahun 2010 tentang BUM Desa 